\title{
The Double Discrimination: A Lived Experience of Female Humanities Teachers in Iran
}

\author{
Zahra Naghshband ${ }^{1}$, Zahra Yavand Taheri ${ }^{2}$ \\ ${ }^{1}$ Sociology Ph.D. student at Al-Zahra University \\ ${ }^{2}$ Master of Sociology of Tehran University
}

\begin{abstract}
From the early 1990s, along with implementing structural adjustment policies, outsourcing education to the private sector and privatizing schools in Iran, especially in industrial cities, has been intensified. Today, 30 percent of Tehran's schools and 18 percent of the whole country's schools are being managed by the private sector. As a result of the commodification of education, not only educational justice is endangered, but also teachers' working lives are wholly affected. Since the recent changes in teachers' employment, the non-appointed teachers (over 100,000 teachers) have to live under temporary and insecure employment conditions. Given the gender gap in the Iranian labor market and the prevailing ideological mindset in education, women, especially non-appointed teachers of humanities, are experiencing a double discrimination.
\end{abstract}

The Systematic monitoring of these female labor forces in private schools takes place through mechanisms such as controlling the educational content and dictating teaching methods, despecializing the workforce and controlling women's daily lives. The process leads to teachers' increasing alienation from the teaching process and takes teaching itself out of a democratic, critical, and practical function.

By adopting a qualitative research approach and based on conducting in-depth interviews with 30 female humanities teachers working in private schools in Tehran, we have explored in this study, the challenges they are facing throughout their careers. The current study aims to contribute to the academic debates on the precarization and precarious employment to elucidate how the mechanisms and mediations of neoliberal policies have fragmented the teachers' bargaining power over their rights.

Keywords: precarization, female teachers, non-appointed, the commodification of education 